\title{
ANALISIS INTERAKSI GURU DAN SISWA DALAM PEMBELAJARAN BAHASA INDONESIA DI KELAS VII SMP NEGERI 15 KOTA BENGKULU
}

\author{
Junita Lisdia Lisa, Ria Ariesta, dan Agus Joko Purwadi \\ Program Studi Pendidikan Bahasa Indonesia \\ Jurusan Pendidikan Bahasa dan Seni \\ FKIP Universitas Bengkulu \\ Junita lisdialisa@yahoo.co.id
}

\begin{abstract}
Abstrak
Tujuan penelitian ini untuk mendeskripsikan interaksi antara guru dan siswa yang terjadi dalam pembelajaran Bahasa Indonesia di kelas VII SMP Negeri 15 Kota Bengkulu, dengan menggunakan analisis interaksi BIAS (Brown Interaction Analysis System). Pendekatan yang digunakan yaitu pendekatan kualitatif dengan metode deskriptif. Subjek penelitian adalah guru dan siswa di kelas VII SMP Negeri 15 Kota Bengkulu. Objek penelitian adalah interaksi guru dan siswa dalam pembelajaran Bahasa Indonesia. Teknik pengumpulan data yang digunakan adalah teknik observasi, wawancara. Hasil penelitian menjelaskan bahwa kecenderungan kategori yang muncul pada kegiatan pembelajaran di kelas VII B dan VII C memiliki perbedaan. Berdasarkan tujuh kategori Brown kategori yang cenderung muncul di dalam pembelajaran Bahasa Indonesia di kelas VII B adalah kategori respon siswa (Pupil Respons (PR) siswa lebih banyak berbicara baik berkomentar maupun bertanya, interaksi yang terjadi adalah interaksi dua arah, hal ini berkaitan dengan keterampilan berbicara dan karakteristik materi yang diajarkan. Di kelas VII C kategori yang cenderung muncul adalah kategori pertanyaan guru (Teacher Questions (TQ) yaitu guru yang lebih dominan mengajukan pertanyaan kepada siswa. Interaksi yang terjadi adalah interaksi dua arah karena ketika guru mengajukan pertanyaan beberapa siswa menjawab pertanyaan guru tersebut. Namun, hanya sebatas antara guru dengan siswa atau siswa dengan guru. Interaksi yang terjadi berkaitan dengan karakteristik materi yang diajarkan dan keterampilan yang harus dicapai oleh siswa setelah pembelajaran selesai.
\end{abstract}

Kata kunci: interaksi, guru dan siswa

\begin{abstract}
Abstrak
The purpose of this research to describe the interaction both of teacher and students which happen in Indonesia Language learning at class VII of SMPN 15 Bengkulu City, by using BIAS interaction analysis (Brown Interaction Analysis System). This study used qualitative approach with descriptive method. The subject of study was teacher and students in the class VII of SMPN 15 Bengkulu City. The object of study was teacher and students interaction in Indonesia Language learning. The teachnique of collecting data used were observation, interview teachnique. The result of research explained that the tendency of categories that appear in learning activity at class VII B and VII C was different. Based on seven categories of Brown, pupil respon (PR) category is tended to appear in Indonesia Language learning at class VII B most of students prefer in speaking activity both in giving comment and asking, the interaction which happen was two directions interaction, this is related to the speaking skill and characteristic of the
\end{abstract}


material being taught. At the class VII C teacher questions (TQ) category is tended to appear where the teacher was giving questions to the students dominantly. The interaction which happen was two direction interaction because when teacher was giving questions then some of students were answer the questions. But, only limited to the teacher and students or students and teacher. The interaction which happen is related to characteristic of the material being taught and skill that students must be achieved after learning is completed.

\section{Keywords: interaction, teacher and student}

\section{PENDAHULUAN}

Pembelajaran merupakan proses interaksi antara siswa dengan lingkungan yang menyebabkan perubahan perilaku ke arah lebih baik. Kegiatan pembelajaran memiliki keterkaitan antara komponen satu sama lain sehingga dapat saling mempengaruhi pada pencapaian dan keberhasilan di dalam proses belajarmengajar. Di antara beberapa komponen di dalam kegiatan pembelajaran, seorang guru juga menjadi salah satu faktor terpenting penunjang keberhasilan belajarmengajar, sebab guru merupakan seorang motivator, fasilitator, inspirator dan evaluator di kelas. Komunikasi antara dua subjek guru dan siswa adalah komunikasi yang dipengaruhi oleh berbagai faktor lainya (Muslich, Hasanah dan Saliwangi, 1987:95). Supaya komunikasi itu terarah, maka komunikasi tersebut harus mempunyai tujuan. Tujuan ini dapat tercapai dengan baik, jika komunikasi itu berlangsung secara optimal, yaitu komunikasi yang bersifat dua arah, ada hubungan timbal balik, dan sebagainya. Di dalam dunia pendidikan dikenal dengan istilah interaksi edukatif. Interaksi edukatif adalah proses interaksi yang disengaja dan sadar tujuan, yakni untuk mengantarkan anak didik ke tingkat kedewasaannya (Sardiman, 2010:8).

Menurut Supriyadi (2011:69), di dalam proses pembelajaran di sekolah sekurang-kurangnya melibatkan empat komponen pokok, yaitu: 1) Individu siswa, 2) guru, 3) ruang kelas 4) kelompok siswa. Semua komponen ini sudah barang tentu memiliki karakteristik sendiri-sendiri yang unik dan berpengaruh terhadap jalanya PBM. Melalui interaksi antara guru dengan siswa dan interaksi antar sesama siswa (komunikasi dua arah dan multiarah) dalam PBM akan menimbulkan perubahan perilaku siswa baik yang berdimensi ranah cipta, ranah rasa maupun ranah karsa.

Menurut (Hadiat, 1980:2), analisis interaksi merupakan serangkaian kejadiankejadian yang spesifik antara guru dan siswa di dalam suatu proses belajarmengajar, diperoleh dengan cara direkam dan dicatat, sehingga didapatkan suatu gambaran mengenai pola interaksi yang terjadi. Brown (dalam Hadiat, 1980:3) mengelompokkan kegiatan guru dan murid yang terjadi selama proses belajarmengajar di dalam kelas menjadi tujuh kelompok. Pola interaksi menurut pengelompokkan yang disusun Brown ini biasa dinamai BIAS (Brown Interaction Analysis System).

Pengelompokkan kegiatan guru dan murid menurut Brown (Bias Categories) yaitu: 1) Ceramah, apabila guru hanya memberi informasi (Teacher Lectures $=\mathrm{TL}$ ). Ceramah sifatnya menerangkan,menguraikan, mengarahkan dan menceritakan. 2) Pertanyaan guru (Teacher Question=TQ), pertanyaan mengenai isi atau pertanyaan yang sifatnya 
mengarahkan. 3) Respon guru (Teacher Respon=TR), sebagai respon guru terhadap murid dapat dinyatakan dengan sikap memuji, bergurau, menerima dan menggunakan buah pikiran siswa, mengembangkan jawaban-jawaban siswa. Ketika menilai hasil pekerjaan siswa atau jawaban siswa sering menggunakan katakata seperti: jawaban itu kurang tepat, lebih baik, seandainya; dan sebagainya. 4) Respon murid (Pupil Respon=PR), respon murid dapat berupa jawaban pertanyaan guru dan juga dapat berupa pertanyaan murid yang maksudnya meminta penjelasan lebih lanjut. 5) Voluntir (Pupil Volunteers $=\mathrm{PV}$ ), tanpa ada perintah murid mengajukan pertanyaan, atau mengemukakan komentar terhadap guru atau sesama murid. 6) Tenang, tidak terjadi apa-apa (Silence=S), dalam keadaan diam. 7) Tidak termasuk kategori 1 sampai dengan 6 (Unclassifiable=X). Tidak dapat diklasifikasikan ke 1 sampai dengan 6 atau sama sekali sulit untuk dinyatakan kepada salah satu kategori tertentu. Kebingungan di mana komunikasi tidak dapat dipahami; kegiatan yang tidak biasa seperti menegur atau mengkritik murid, berdemonstrasi tanpa didampingi guru atau pembicaraan murid; serentetan pendek kerja papan tulis tanpa mendampingi guru atau murid bekerja, sehingga tidak terjadi interaksi.

Kurikulum 2013 lebih menekankan pada siswa yang lebih aktif dan mandiri. Proses pembelajaran pada Kurikulum 2013 untuk semua jenjang dilaksanakan dengan menggunakan pendekatan ilmiah (saintifik) dan menggunakan penilaian autentik. Penerapan pendekatan ilmiah dalam pembelajaran melibatkan keterampilan proses yang esensial, yaitu mengamati, menanya, menalar, mencoba, dan mengomunikasikan. Penilaian pencapaian kompetensi dasar siswa pada Kurikulum 2013 dilakukan dengan menggunakan penilaian autentik, yaitu penilaian yang mengukur kompetensi sikap, pengetahuan, dan keterampilan terhadap proses dan hasil yang sebagaimana adanya. Penilaian ini dilakukan dengan menggunakan tes dan nontes baik dalam bentuk lisan maupun tertulis, pengamatan sikap, penggunaan portofolio, dan penilaian hasil karya berupa tugas proyek atau produk.

Dasar masalah yang menjadi latar belakang penelitian ini disebabkan oleh Kurikulum yang digunakan sudah 2013 tetapi guru masih mendominasikan kelas, sehingga peran siswa kurang aktif di dalam proses pembelajaran, dan karakteristik materi dalam pembelajaran Bahasa Indonesia yaitu empat keterampilan bahasa kurang ditekankan sesuai dengan kompetensi dasar yang akan dipelajari.

Permasalahan tentang interaksi dalam proses pembelajaran Bahasa Indonesia antara guru dan siswa di kelas VII dijadikan fokus dalam penelitian. Penelitian ini akan dilakukan di SMP Negeri 15 Kota Bengkulu dengan alasan sekolah ini yang sudah menerapkan Kurikulum 2013, kemudian lokasi penelitian yang cukup strategis dan lebih mudah dijangkau oleh peneliti. Peneliti memilih satuan pendidikan SMP dengan alasan tingkat SMP merupakan masa yang masih baru akan mengalami perubahan baik dari segi mental, fisik juga kognitifnya, sehingga peneliti tertarik untuk menganalisis interaksi yang terjadi antara siswa dengan guru ketika proses pembelajaran terjadi.

Penelitian ini penting dilakukan, karena bertujuan untuk mendeskripsikan interaksi yang terjadi antara guru dan siswa dalam pembelajaran Bahasa Indonesia di kelas VII, selain itu dengan penelitian ini dapat menjadi tolak ukur untuk memaksimalkan dan meningkatkan interaksi yang lebih baik antara guru dan siswa terutama dalam pembelajaran Bahasa Indonesia. Peneliti beranggapan bahwa interaksi yang terjadi di dalam proses pembelajaran yang menggunakan Kurikulum 2013 belum dimaksimalkan. 


\section{METODE}

Metode yang digunakan dalam peneltian ini adalah metode deskriptif kualitatif yang bertujuan untuk mendeskripsikan interaksi guru dan siswa di kelas VII SMP Negeri 15 Kota Bengkulu. Penelitian ini dilaksanakan di SMP Negeri 15 Kota Bengkulu. Data yang digunakan di dalam penelitian ini berupa data primer dan data sekunder. Data primer berupa data yang secara langsung diperoleh oleh peneliti di lapangan yaitu, ketika kegiatan proses pembelajaran Bahasa Indonesia antara guru dan siswa di kelas VII B dan VII $C$ dan hasil wawancara. Data sekunder berupa data yang diperoleh secara tidak langsung dari pengumpulan informasi dari berbagai bentuk dokumen seperti Rencana Pelaksanaan Pembelajaran (RPP). Sumber data yang digunakan adalah seorang guru Bahasa Indonesia, serta siswa kelas VII B dan VII C SMP Negeri 15 Kota Bengkulu di dalam kegiatan pembelajaran di kelas.

Teknik pengumpulan data yang digunakan dalam proses mengumpulkan data yaitu dengan menggunakan teknik observasi (pengamatan), teknik interview (wawancara), dan dokumen. Pada instrumen penelitian, peneliti menggunakan instrumen atau alat penelitian yaitu peneliti itu sendiri.

Analisis data dilakukan dengan langkah-langkah sebagai berikut (1) peneliti mentranskipkan data lisan antara guru dan siswa yang berupa percakapan dari rekaman ke dalam bahasa tulisan. (2) memberikan kode ujaran guru berdasarkan tujuh kategori analisis interaksi BIAS (Brown Alaysis Interaction System). (3) mengidentifikasi kegiatan guru dan siswa ke dalam kegiatan pembelajaran yaitu kegiatan awal, inti, akhir pembelajaran. (4) mengklasifikasikan data ke dalam tujuh kategori BIAS (Brown Interaction Analysis System) yaitu terdiri dari ceramah yakni bila guru hanya memberikan informasi (Teacher Leatures (TL), pertanyaan guru (Teacher
Question (TQ), Respon guru (Teacher Respon (TR), Respon Murid (Pupil Respon $(P R)$,Voluntir (Pupil Volunteers (PV), tenang yaitu tidak terjadi apa-apa (Silence $(S)$ dan yang terakhir tidak termasuk kategori 1 sampai 6 Unclassifable $(X)$. menyimpulkan interaksi yang terjadi di dalam proses pembelajaran di kelas VII B dan VII C di SMP Negeri 15 Kota Bengkulu.

\section{HASIL PENELITIAN DAN PEMBAHASAN} Hasil

Hasil penelitian tentang analisis interaksi guru dan siswa dalam pembelajaran Bahasa Indonesia di kelas VII SMP Negeri 15 Kota Bengkulu diperoleh data dan dianalisis menggunakan pola interaksi BIAS (Brown Interaction Analysis System) yang terdiri dari tujuh kategori yaitu: (1) Ceramah (Teacher Lectures (TL), (2) pertanyaan guru (Teacher Questions (TQ), (3) respon guru (Teacher Respon (TR), (4) respon murid (Pupil Respons (PR), (5) voluntir (Pupil Volunteers (PV), (6) tenang (Silence (S), (7) dan tidak termasuk 6 kategori di atas karena tidak dapat dikategorikan (Unclassifiable $(X)$. Interaksi yang terjadi dalam proses pembelajaran di kelas VII B dan VII C sama-sama bersifat dua arah, akan tetapi kategori yang muncul pada kegiatan pembelajaran antara kedua kelas tersebut berbeda. Data tersebut diperoleh dari lembar kisi-kisi observasi yang dilakukan sebanyak dua kali pertemuan setiap kelas.

Tabel 1. Hasil Observasi pertemuan pertama di kelas VII B

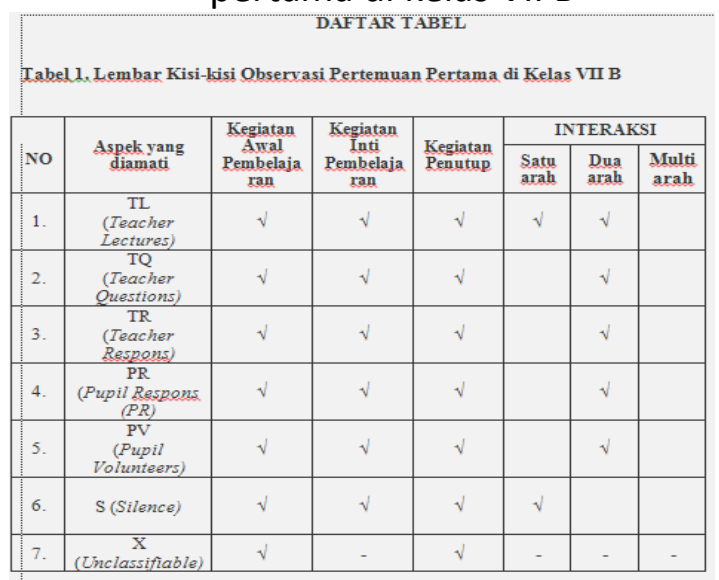


Tabel 2. Hasil Observasi pertemuan kedua di kelas VII B

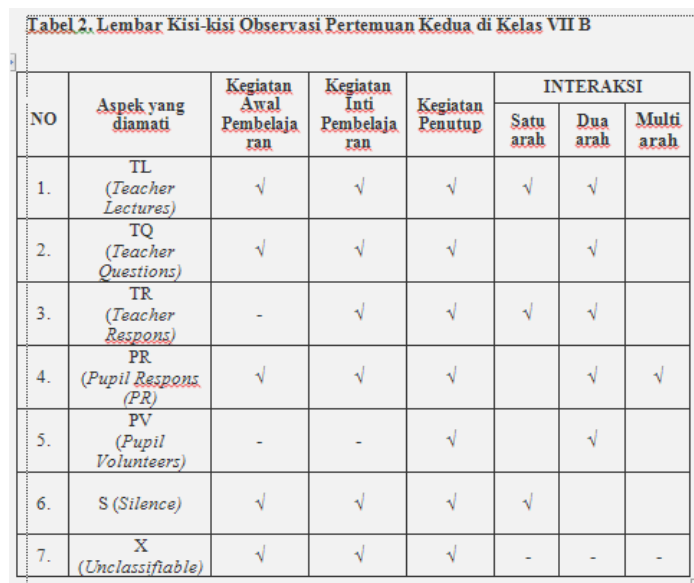

1. Ceramah.

Apabila guru memberikan Informasi.

(Teacher Lectures (TL)

Kegiatan guru berceramah bukan hanya memberikan siswa informasi dalam proses pembelajaran, akan tetapi ceramah juga dapat berisifat menerangkan, menguraikan, mengarahkan serta menceritakan. Pada kategori ceramah (Teacher Lectures (TL) ketika guru menjelaskan di kelas VII B siswa terlihat siap untuk mengikuti pembelajaran Bahasa Indonesia pada hari ini karena semua siswa duduk dengan rapi, pandangan lurus ke depan dan suasana kelas menjadi tenang. Sebelum pembelajaran berlangsung guru meminta ketua kelas untuk menyiapkan kelas dan berdoa, ha ini terjadi interaksi satu arah karena guru mengarahkan ketua kelas untuk memimpin doa.

(Lampiran 1)

G : "Baiklah, sebelum memulai pembelajaran pada hari ini mari kita berdoa terlebih dahulu, ketua kelas silahkan siapkan kelas dan pimpin doa. (Teacher Lectures (TL)

$\mathrm{S}_{1} \quad$ : "Bersedia, berisalam kepada Ibu Guru. (Pupil Respon (PR)

Kegiatan inti pembelajaran guru menjelaskan pengantar mengenai buku fiksi dan nonfiksi. Disaat kegiatan tersebut siswa memperhatikan apa yang sedang dijelaskan oleh guru. Setelah menjelaskan, guru mengajukan pertanyaan kepada siswa namun beberapa detik suasana menjadi hening, tidak ada satupun yang berbicara, akan tetapi selang waktu beberapa menit barulah terlihat salah satu siswa menjawab pertanyaan guru tersebut hal ini dapat dilihat pada kutipan di bawah ini:

G : "Ayo, siapa yang bisa jawab, semua buku itu punya apa? (Teacher Questions (TQ)

Keadaan kelas menjadi tenang, tidak ada yang beribicara sedikitpun (Silence (S)

$\mathrm{S}_{1} \quad$ : "Saya Bu. Judul Bu" (Pupil Volunteers (PV)

G : "lya judul. Semua buku pasti memiliki judul, apabila sebuah buku tidak ada judul maka nilai jual dan kualitasnya menjadi kurang baik karena judul merupakan daya tarik pertama begai pembaca. (Teacher Respons (TR)

G : "Selain dari judul, apa lagi yang harus dimiliki oleh sebuah buku, iya Rara menurut kamu apa?"

$\mathrm{S}_{1} \quad$ : "Tema Bu". (Pupil Respons (PR)

Berdasarkan kutipan di atas terlihat bahwa ketika guru menjelaskan materi pembelajaran pada kegiatan inti pembelajaran interaksi yang terjadi bersifat dua arah karena pada kategori ceramah (Teacher Lectures (TL) guru tidak hanya menjelaskan materi pembelajaran hingga selesai, guru mengajukan pertanyaan kepada siswa kemudian salah satu siswa menjawab pertanyaan tersebut, kemudian guru merespon jawaban siswa dengan menambah dan memperluas jawaban.

\section{Pertanyaan guru (Teacher Questions (TQ)}

Pertanyaan guru (Teacher Questions (TQ) merupakan bentuk dari kegiatan di dalam proses pembelajaran yang melibatkan siswa dan guru tetapi lebih difokuskan kepada guru. 
(Lampiran 1)

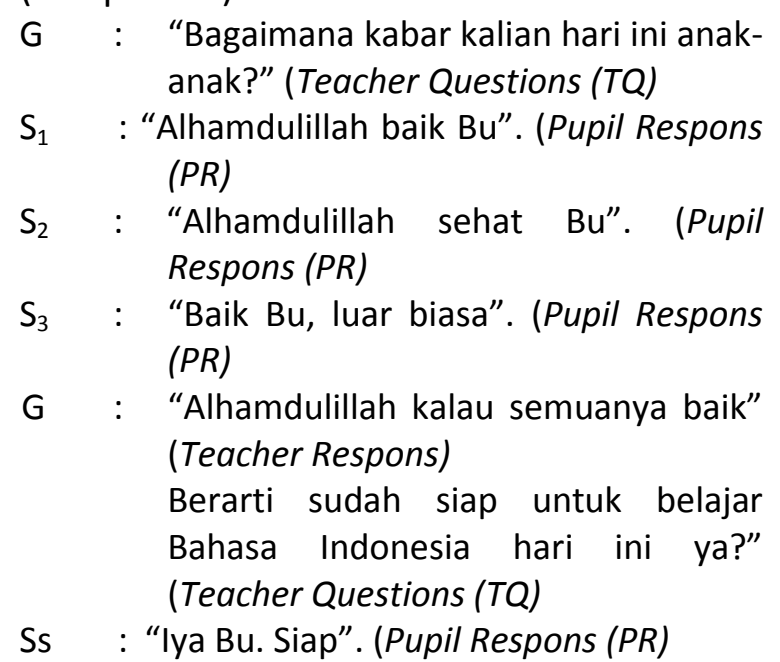

Berdasarkan kutipan di atas terlihat bahwa sebelum kegiatan pembelajaran dimulai siswa-siswi terlihat bersemangat untuk memulai pembelajaran pada hari ini. Interaksi yang terjadi di dalam kegiatan belajar-mengajar Bahasa Indonesia bersifat dua arah karena ketika guru bertanya kabar siswa satu menjawab, kemudian siswa dua lainya ikut merespon pertanyaan guru tersebut. Kemudian guru kembali merespon jawaban siswa dan kembali mengajukan pertanyaan bahwa apakah siswa-siswi tersebut sudah siap untuk belajar Bahasa Inonesia.

\section{Respon guru (Teacher Respons (TR)}

Respon guru merupakan kegiatan guru ketika merespon siswanya baik dengan sikap memuji, bergurau, menerima, menggunakan atau mengembangkan buah pikiran siswa.

G : "Bagaimana kabar kalian hari ini anakanak?" (Teacher Questions (TQ)

$\mathrm{S}_{1}$ : "Alhamdulillah baik Bu". (Pupil Respons (PR)

$\mathrm{S}_{2}$ : "Alhamdulillah sehat Bu". (Pupil Respons (PR)

$\mathrm{S}_{3} \quad$ : "Baik Bu, luar biasa". (Pupil Respons (PR)

G : "Alhamdulillah kalau semuanya baik" (Teacher Respons)
Berarti sudah siap untuk belajar Bahasa Indonesia hari ini ya?" (Teacher Questions (TQ)

Siswa-siswi terlihat bersemangat ketika guru bertanya kabar mereka sebelum pembelajaran dimulai. Tidak hanya satu siswa yang menjawab, tetapi siswa lainya ikut menanggapi pertanyaan guru tersebut. setelah mendengar jawaban-jawaban dari siswanya guru merespon kembali dengan mengucapkan rasa syukur Alhamdulillah. Interaksi yang terjadi pada kategori ini bersifat dua arah, karena hanya memiliki keterkaitan secara individual antara guru dan siswa, tidak dengan siswa satu dengan siswa lainya.

\section{Respon murid (Pupil Respons (PR)}

Respon murid merupakan kegiatan yang dilakukan oleh siswa ketika menjawab pertanyaan dari guru, pertanyaan sekelasnya, atau pertanyaan siswa ke guru untuk meminta penjelasan yang lebih lanjut. Berdasarkan hasil observasi yang dilakukan pada kegiatan pembelajaran Bahasa Indonesia di kelas VII B, siswa memberikan respon kepada guru atau kepada siswa lainya baik sebagai sebuah jawaban atau sebuah pendapat berkaitan dengan materi pembelajaran pada hari itu atau diluar dari konteks. Pada kategori ini interaksi yang terjadi bersifat dua arah karena komunikasi yang terjadi antara guru dan siswa dapat berperan sebagai pemberi aksi dan penerima aksi.

Siswa terlihat begitu antusias ketika merespon pertanyaan guru meski tidak semua siswa yang berbicara. Hal ini dapat dilihat pada kutipan di bawah ini:

G : "Baiklah sebelum memulai pelajaran Ibu absen dulu". (Unclassifiable $(X)$

Ss : "Iya Buu". (Pupil Respon (PR)

$\mathrm{G}$ : "Bagaimana kabar kalian hari ini anakanak?" (Teacher Questions (TQ)

$\mathrm{S}_{1} \quad$ : "Alhamdulillah baik Bu". (Pupil Respons $(P R)$ 
$\mathrm{S}_{2} \quad$ : "Alhamdulillah sehat Bu". (Pupil Respons $(P R)$

5. Voluntir (Pupil Volunteers (PV)

Voluntir (Pupil Volunteers (PV)

merupakan kegiatan dimana seorang siswa tanpa adanya perintah dari guru mengajukan pertanyaan atau mengemukakan komentar. Berdasarkan hasil observasi yang dilakukan pada kegiatan pembelajaran Bahasa Indonesia di kelas VII B kategori ini terjadi ketika guru mengajukan pertanyaan kemudian siswa tanpa adanya perintah mengangkat tanganya dan menjawab pertanyaan tersebut, interaksi yang terjadi pada kategori respon siswa adalah interaksi dua arah. Hal ini dapat dilihat pada kutipan di bawah ini:

G : "Sebelum pembelajaran berakhir Ibu ingin bertanya kepada kalian terlebih dahulu, siapa yang masih ingat apa perbedaan antara buku fiksi dengan buku nonfiksi? (Teacher Questions (TQ)

Keadaan kelas menjadi tenang, tidak ada yang berbicara sedikitpun (Silence (S)

$\mathrm{S}_{1} \quad$ : "Saya Bu" (Mengangkat tangan). Buku fiksi adalah buku yang bersifat imajinasi atau khayalan. Sedangkan buku nonfiksi adalah buku yang bersifat ilmu pengetahuan atau pembelajaran yang dapat menambah wawasan pembecanya. (Pupil Volunteers (PV)

6. Tenang, tidak terjadi apa-apa (Silence (S) Kategori ini merupakan keadaan tenang atau diam sejenak saat kegiatan belajar mengajar. Berdasarkan kegiatan hasil observasi kategori ini terjadi pada kegiatan awal pembelajaran dan pada saat kegiatan inti pembelajaran. Pada kegiatan awal pembelajaran yaitu pada saat semua siswa berdoa sebelum memulai pembelajaran, keadaan menjadi tenang sejenak karena semua siswa khusyuk memanjatkan doa. Interaksi yang terjadi tidak ada karena pada kegiatan ini komunikasi tidak terjadi antara guru dengan siswa atau antara siswa dengan siswa. Dapat dilihat pada kutipan di bawah ini:

G :"Baiklah, sebelum memulai pembelajaran pada hari ini mari kita berdoa terlebih dahulu, ketua kelas silahkan siapkan kelas dan pimpin doa. (Teacher Lectures (TL)

$\mathrm{S}_{1} \quad$ : "Berdoa mulai". (Silence $(S)$

$\mathrm{S}_{1} \quad$ : "Berdoa selesai". (Silence (S)

Pada kegiatan inti dan kegiatan akhir pembelajaran Bahasa Indonesia kategori tenang, atau tidak terjadi apa-apa (silence $(S)$ terjadi pada saat guru bertanya akan tetapi tidak ada seorangpun yang menjawab pertanyaan, tiba-tiba keadaan kelas menjadi tenang karena dalam waktu beberapa detik semua siswa tidak ada yang berbicara. Hal ini terlihat bahwa interaksi yang terjadi bersifat satu arah karena guru berperan sebagai pemberi aksi, siswa menjadi pasif. Hal ini dapat dilihat pada kutipan di bawah ini:

G : "Ayo, siapa yang bisa jawab, semua buku itu punya apa? (Teacher Questions (TQ)

Keadaan kelas menjadi tenang, tidak ada yang beribicara sedikitpun (Silence $(S)$

7. Tidak termasuk kategori 1 s/d 6 (Unclassifiable $(X)$

Kategori (unclassifiable $(x)$ merupakan kategori yang tidak dapat diklasifikasikan. Pada kategori ini terjadi kebingungan karena komuikasi tidak dapat dipahami. Pada kegiatan pembelajaran Bahasa Indonesia kategori ini ada pada kegiatan awal dan akhir pembelajaran, interaksi yang terjadi tidak ada. pada pada kategori ini karena tidak dapat diklasifikasikan. Hal ini dapat dilihat pada kutipan di bawah ini: (Kegiatan Awal Pembelajaran) 
G : "Baiklah, sebelum memulai pembelajaran pada hari ini mari kita berdoa terlebih dahulu, ketua kelas silahkan siapkan kelas dan pimpin doa. (Teacher Lectures (TL)

$\mathrm{S}_{1}$ : "Bersedia. berisalam kepada Ibu Guru. (Pupil Respon (PR)

Ss : "Assalamualaikum Warrohmatullahi Wabarrokatuh". (Unclassifable (X)

G : "Waalaikumsalam Warrohmatullahi Wabarrokatuh". (Unclassifable (X)

(Kegiatan Akhir Pembelajaran)

G : "Baiklah ketua kelas silahkan siapkan (Teacher Lectures (TL)

$\mathrm{S}_{1} \quad$ : "Baik Bu. Bersedia, beri salam kepada Ibu guru" (Pupil Respons (PR)

Ss : "Assalamualaikum Warrohmatullahi Wabarrokatuh" (Unclassifiable (X)

G : "Waalaikumsalam Warrohmatullahi Wabarrokatuh" (Unclassifiable (X)

Berdasarkan kutipan di atas terlihat bahwa ucapan salam yang diucapkan sebelum memulai pebelajaran dan ketika akan mengakhiri pembelajaran tidak dapat diklasifikasikan dan dikategorikan, hal ini menyebabkan interaksi yang terjadi pada kategori ini juga tidak ada.

Tabel 3. Hasil Observasi pertemuan pertama di kelas VII C

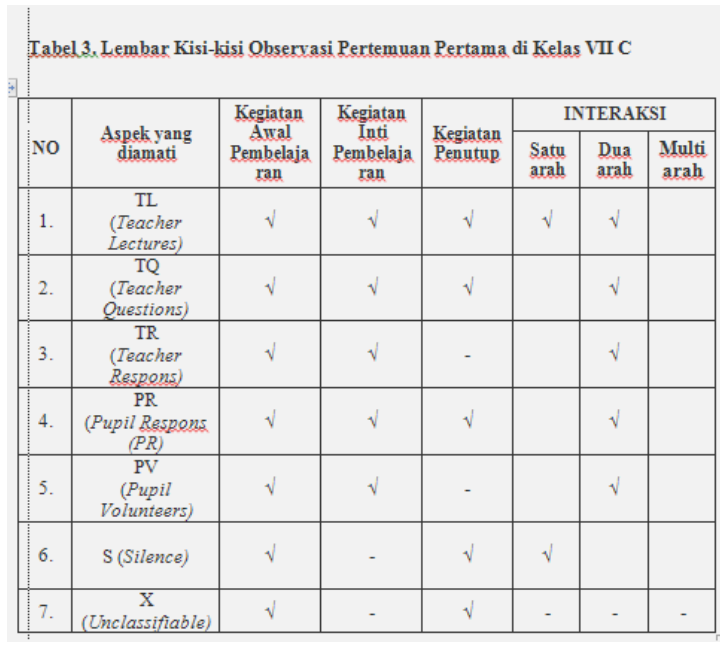

Tabel 4. Hasil Observasi pertemuan kedua di kelas VII C

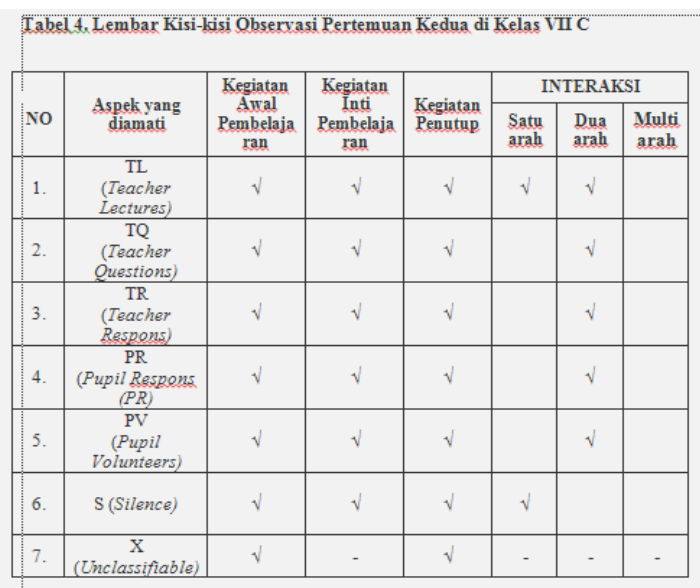

1. Ceramah.

Apabila guru memberikan Informasi. (Teacher Lectures (TL)

Kegiatan guru berceramah bukan hanya memberikan siswa informasi dalam proses pembelajaran, akan tetapi ceramah juga dapat bersifat menerangkan, menguraikan, mengarahkan serta menceritakan. Berdasarkan hasil observasi yang dilakukan pada pertemuan pertama saat pembelajaran Bahasa Indonesia di kelas VII C, kegiatan ceramah pada kegiatan awal pembelajaran guru terlebih dahulu mengarahkan siswa untuk berdoa, mengabsen siswa, bertanya kabar dan memberikan penjelaskan materi hari ini berkaitan dengan kejadian di kelas yaitu banyak siswa yang tidak masuk sekolah. Kegiatan tersebut terjadi antara guru dan siswa dimana guru berperan sebagai pemberi aksi sedangkan siswa sebagai penerima aksi, hal ini termasuk ke dalam interaksi satu arah, hal ini dapat dilihat pada kutipan di bawah ini.

\section{(Lampiran 1)}

G : :Baiklah sebelum memulai pelajaran kita berdoa terlebih dahulu ya, ketua kelas siapkan kelasnya" (Teacher Lectures (TL)

$\mathrm{S}_{1} \quad$ : "Baik Bu. Bersedia beri salam kepada Ibu Guru". (Pupil Respon (PR)

$\mathrm{S}_{1} \quad$ : "Berdoa mulai". (Silence $(S)$

$\mathrm{S}_{1} \quad$ : "Berdoa selesai". (Silence $(S)$ 


\section{Pertanyaan guru (Teacher Questions (TQ)}

Kategori pertanyaan guru (Teacher Questions (TQ) pada kegiatan pembelajaran Bahasa Indonesia di kelas VII C, terdapat di setiap kegiatan pembelajaran baik pada dikegiatan awal, inti dan akhir pembelajaran. Pada kegiatan inti pembelajaran kategori ini terjadi ketika guru menjelaskan materi, kemudian guru mengajukan pertanyaan-pertanyaaan yang sifatnya untuk mengingat, mengevaluasi, atau pemahaman, sintesis atau jenis pertanyaan lainya. Hal ini dapat dilihat pada kutipan di bawah ini:

G : "Tujuan kita mengirim surat itu untuk apa? (Teacher Questions (TQ)

Mengapa kita harus mengirim surat? Surat pribadi misalnya kita megirim surat untuk keluarga kita, nenek kita atau saudara kita?" Mengapa kita harus berkirim surat? Siapa yang bisa jawab? (Teacher Questions (TQ)

Itu bernalar tidak ada di dalam buku". (Teacher Respons (TR)

G : "Vito? Apakah kamu pernah berkirim surat dengan keluarga? (Teacher Questions (TQ)

$\mathrm{S}_{2}$ : "Tidak pernah Bu". (Pupil Respons (PR)

Berdasarkan kutipan di atas terlihat bahwa guru mengajukan pertanyaan kognitif. Pertanyaan kognitif adalah pertanyaan yang dilakukan guru kepada siswa dengan tujuan untuk menguji pengetahuan, pemahaman, dan pendapat siswa tentang materi pelajaran. Interaksi yang terjadi bersifat satu arah.

\section{Respon guru (Teacher Respons (TR)}

Respon guru merupakan kegiatan guru ketika merespon siswanya baik dengan sikap memuji, bergurau, menerima, menggunakan atau mengembangkan buah pikiran siswa. Berdasarkan hasil observasi kedua yang dilakukan pada saat pembelajaran Bahasa Indonesia di kelas VII $C$, kategori respon guru hanya terdapat pada kegiatan awal dan kegiatan inti pembelajaran. Pada kegiatan inti pembelajaran kategori respon guru ada ketika ada siswa yang menjawab pertanyaan yang diajukan oleh guru. Hal ini dapat dilihat pada kutipan di bawah ini:

$\mathrm{S}_{3} \quad$ : "Ada lagi Bu yaitu surat cinta Bu". (Pupil Volunteers (PV)

G : "Ya, itu bisa termasuk juga surat cinta merupakan bagian dari sejarah. (Teacher Respons (TR) Selain itu apalagi tujuan dibuatnya surat?" (Teacher Questions (TQ)

$S_{1} \quad$ : "Sebagai pedoman pelaksanaan tugas". (Pupil Respons (PR)

G : "Iya sebagai pedoman pelaksanaan tugas, contohnya seperti SK. Kalau kamu ikut di OSIS kamu dapat SK kan, nah itu namanya surat pembagian tugas (Teacher Respons (TR).

Berdasarkan kutipan di atas guru merespon jawaban siswa dengan mengembangkan jawaban siswa agar jawaban tersebut dapat lebih luas dan pemahaman siswa juga dapat bertambah. Pada kategori tersebut interaksi yang terjadi dua arah karena ketika siswa bertanya, guru memberikan respon hal ini terjadi hubungan timbal balik antara dua orang yang mana guru memberikan penjelasan dan siswa menerima informasi yang disampaikan.

\section{Respon Murid (Pupil Respons (PR)}

Respon murid (Pupil Respons (PR) merupakan kegiatan yang dilakukan oleh siswa ketika menjawab pertanyaan dari guru, pertanyaan dari teman sekelasnya, atau pertanyaan siswa ke guru untuk meminta penjelasan yang lebih lanjut. Kategori ini selalu ada pada setiap kegiatan pembelajaran, baik pada kegiatan awal, inti dan akhir pembeljaran. Pada kegiatan inti pembelajaran Bahasa Indonesia di kelas VII C, kategori ini terjadi ketika Pada kegiatan inti pembelajaran kategori respon siswa muncul ketika guru mengajukan 
pertanyaan, hal ini menimbulkan respon berupa jawaban-jawaban berkaitan dengan materi atau di luar dari materi. Kegiatan respon murid dapat dilihat pada kutipan di bawah ini:

(Pertemuan Pertama di kelas VII C, lampiran 1)

G : "Mengapa kita harus berkirim surat? (Teacher Questions (TQ)

Sesuai dengan tujuan yakni untuk menyampaikan informasi. Jika seseorang yang kita tuju ada disekitar kita dan berada pasa situasi yang sama (Teacher Lectures (TL)

Sekarang Ibu beri contoh : rata-rata kita berada di provinsi Bengkulu, misalnya ibu orang Sunda dan berbicara dengan kalian yang mayoritas menggunakan bahasa Bengkulu (Teacher Lecture (TL)

Apakah informasi atau tujuan yang ingin ibu bicarakan dapat tersampaikan tidak dengan kalian?" (Teacher Questions (TQ)

Ss : "Tidakkk bisa tersampai Bu". (Pupil Respons (PR)

G : "Mengapa?” (Teacher Questions (TQ)

$\mathrm{S}_{1} \quad$ : "Karena beda bahasa". (Pupil Respons (PR)

G : "Karena beda bahasa, atau bahasa tersebut tidak komunikatif. (Teacher Respons (TR)

Jadi bahasa yang komunikatif itu yang bagaimana dan bahasa yang seperti apa sebenarnya?" (Teacher Questions (TQ)

$\mathrm{S}_{2} \quad$ : "Bahasa yang tepat". (Pupil Respons $(P R)$

Interaksi yang terjadi pada kategori ini bersifat dua arah karena terlihat ketika salah satu siswa merespon pertanyaan guru, siswa lainya juga menjawab namun hubungan dan keterkaitan antara siswa satu dengan siswa yang lain tidak terlihat. Hal ini hanya terlihat hubungan dua arah antara guru dan siwa.

\section{Voluntir (Pupil Volunteers (PV)}

Voluntir atau (Pupil Volunteers) merupakan kegiatan dimana seseorang tanpa adanya perintah dari guru mengajukan pertanyaan atau mengemukakan komentar. Pada hasil observasi yang dilakukan di kelas VII C pada pembelajaran Bahasa Indonesia kategori ini hanya terlihat pada kegiatan awal dan inti pembelajaran.

(Lampiran 1)

G : "Hari ini banyak yang tidak hadir ya, nah kira-kira apa yang harus kita sampaikan sebagai siswa jika kita tidak hadir sekolah? (Teacher Lectures (TL)

Secara resmi ya, bukan mengirim pesan kepada teman untuk memberitahukan ke pada guru bahwa tidak bisa hadir ke sekolah pada hari ini. (Teacher Lectures (TL)

Kira-kira apa yang harus diberikan? Pengumuman kah? (Teacher Questions(TQ)

Keadaan kelas menjadi tenang kembali, tidak ada yang berbicara sedikitpun (Silence (S)

$\mathrm{S}_{1}:$ (Mengangkat tangan) Surat izin Bu" (Pupil Volunteers (PV)

Berdasarkan kutipan di atas salah satu siswa terlihat mengangkat tangan dan menjawab pertanyaan tanpa adanya perintah dari guru, hal tersebut sangat baik karena proses pembelajaran memang harus menuntut siswa lebih mandiri dan aktif tanpa adanya perintah atau arahan dari guru. Interaksi yang terjadi pada kategori ini bersifat dua arah karena hanya berhubungan dengan dua orang yaitu guru dan siswa, tanpa ada komentar atau sanggahan dari siswa lainya.

6. Tenang, tidak terjadi apa-apa (Silence (S)

Kategori ini merupakan keadaan tenang atau diam sejenak saat kegiatan belajar mengajar. Berdasarkan kegiatan hasil observasi kedua kategori ini terjadi 
pada kegiatan awal pembelajaran dan pada kegiatan akhir pembelajaran. Pada kegiatan awal pembelajaran yaitu pada saat semua siswa berdoa sebelum memulai pembelajaran, keadaan menjadi tenang sejenak karena semua siswa khusyuk memanjatkan doa. Interaksi yang terjadi tidak ada karena pada kegiatan ini komunikasi tidak terjadi antara guru dengan siswa atau antara siswa dengan siswa. Dapat dilihat pada kutipan di bawah ini:

(Pertemuan Pertama di kelas VII C, lampiran 1)

G : "Baiklah sebelum memulai pelajaran kita berdoa terlebih dahulu ya, ketua kelas siapkan kelasnya" (Teacher Lectures (TL)

$\mathrm{S}_{1} \quad$ : "Baik Bu. Bersedia beri salam kepadalbu Guru". (Pupil Respon (PR)

Ss : "Assamualaikum warrohmatullahi wabarrokatuh". (Unclassifiable $(X)$

G : "Wa'alaikumsalam warrohmatullahi wabarrokatuh". (Unclassifiable (X)

$\mathrm{S}_{1} \quad$ : "Berdoa mulai". (Silence $(S)$

$\mathrm{S}_{1} \quad$ : "Berdoa selesai". (Silence $(S)$

7. Tidak termasuk kategori $1 \mathrm{~s} / \mathrm{d} 6$ (Unclassifiable $(X)$

Kategori (unclassifiable $(x)$ merupakan kategori yang tidak dapat diklasifikasikan. Pada kategori ini terjadi kebingungan karena komuikasi tidak dapat dipahami. Berdasarkan kegiatan hasil observasi kedua yang telah dilakukan di kelas VII C. Pada kegiatan pembelajaran Bahasa Indonesia kategori ini ada pada kegiatan awal dan kegiatan akhir pembelajaran. Interaksi yang terjadi tidak ada pada pada kategori ini karena tidak dapat diklasifikasikan. Hal ini dapat dilihat pada kutipan di bawah ini:

(Kegiatan Awal Pembelajaran)

G : "Baiklah, sebelum memulai pembelajaran pada hari ini mari kita berdoa terlebih dahulu, ketua kelas silahkan siapkan kelas dan pimpin doa. (Teacher Lectures (TL)
$\mathrm{S}_{1}$ : "Bersedia. berisalam kepada lbu Guru. (Pupil Respon (PR)

Ss : "Assalamualaikum Warrohmatullahi Wabarrokatuh". (Unclassifable (X)

G : "Waalaikumsalam Warrohmatullahi Wabarrokatuh". (Unclassifable (X)

(Kegiatan Akhir Pembelajaran)

G : "Baiklah ketua kelas silahkan siapkan (Teacher Lectures (TL)

$\mathrm{S}_{1} \quad$ : "Baik Bu. Bersedia, beri salam kepada Ibu guru" (Pupil Respons (PR)

Ss : "Assalamualaikum Warrohmatullahi Wabarrokatuh" (Unclassifiable (X)

G : "Waalaikumsalam Warrohmatullahi Wabarrokatuh" (Unclassifiable (X)

\section{Pembahasan}

Berdasarkan hasil penelitian interaksi pada kegiatan pembelajaran Bahasa Indonesia di kelas VII SMP Negeri 15 Kota Bengkulu dengan menggunakan analisis interaksi menurut BROWN (BIAS=Brown Interaction Analysis System) yang terdiri dari tujuh kategori yaitu: (1) Ceramah (Teacher Lectures (TL), (2) pertanyaan guru (Teacher Questions (TQ), (3) respon guru (Teacher Respon (TR), (4) respon murid (Pupil Respons (PR), (5) voluntir (Pupil Volunteers (PV), (6) tenang (Silence (S), (7) dan tidak termasuk 6 kategori di atas karena tidak dapat dikategorikan (Unclassifiable $(X)$. Kecenderungan kategori yang muncul pada kegiatan pembelajaran di kelas VII B dan VII C berbeda. Di kelas VII B pada pertemuan pertama dan kedua kategori yang cenderung muncul dalam kegiatan pembelajaran Bahasa Indonesia adalah kategori respon siswa (Pupil Respons $(P R)$, kategori ini selalu terlihat pada kegiatan awal, kegiatan inti dan kegiatan akhir pembelajaran. Pada kategori respon siswa (Pupil Respons (PR) interaksi yang terjadi adalah interaksi dua arah. Interaksi dua arah merupakan interaksi yang terjadi sebatas antara guru dan siswa secara individual, antara siswa satu dengan siswa lain tidak ada hubungan. Interaksi 
yang maksimal adalah interaksi yang dapat melibatkan guru dengan siswa, dan siswa dengan siswa lainya. Hal ini sejalan dengan pendapat Nana Sudjana (dalam Sutikno, 2009:66) menjelaskan komunikasi banyak arah atau komunikasi sebagai transaksi tidak hanya melibatkan interaksi dinamis guru dan siswa, tetapi juga melibatkan interaksi dinamis antara siswa yang satu dengan siswa lainya. Materi pembelajaran Bahasa Indonesia di kelas VII B yaitu menentukan unsur-unsur dari buku fiksi dan nonfiksi yang dibaca. Pada materi pembelajaran ini siswa diminta untuk dapat menentukan unsur-unsur buku fiksi dan buku nonfiksi yang dibaca, ketika di kegiatan inti pembelajaran siswa secara berkelompok diminta berkomentar dan memaparkan hasil kerja kelompok mereka. Karateristik materi dengan interaksi yang terjadi di dalam kegiatan pembelajaran di kelas sangat berkaitan karena pada dasarnya kegiatan pembelajaran tergantung dari kompetensi dasar di setiap kali pertemuan dalam kegiatan belajar mengajar.

Di kelas VII C pada pertemuan pertama dan kedua kategori yang cenderung muncul dalam kegiatan pembelajaran Bahasa Indonesia adalah kategori pertanyaan guru (Teacher Questions (TQ), kategori ini selalu terlihat pada kegiatan awal, kegiatan inti dan kegiatan akhir pembelajaran. Pada kategori pertanyaan guru (Teacher Questions (TQ) interaksi yang terjadi adalah interaksi dua arah. Interaksi dua arah merupakan interaksi yang terbatas antara guru dan siswa secara individual, antara siswa satu dengan siswa lain tidak ada hubungan. Interaksi yang baik adalah interaksi yang dapat melibatkan guru dengan siswa, dan siswa dengan siswa lainya sehingga pembelajaran akan lebih efektif. Hal ini sejalan dengan pendapat Nana Sudjana (dalam Sutikno, 2009:66) menjelaskan komunikasi banyak arah atau komunikasi sebagai transaksi tidak hanya melibatkan interaksi dinamis guru dan siswa, tetapi juga melibatkan interaksi dinamis antara siswa yang satu dengan siswa lainya. Kategori pertanyaan guru (Teacher Questions (TQ) termasuk ke dalam pola interaksi guru dan siswa. Hal ini sejalan dengan pendapat (Samana, 1992:105) bahwa pola interaksi guru ke siswa isi pengajaranya meliputi : kegiatan memberi tugas, memberi informasi, memotivasi, membangun apersepsi, memberi umpan balik, dan membina disiplin kelas atau kerja. Berdasarkan tujuh kategori Brown kategori yang cenderung muncul di dalam pembelajaran Bahasa Indonesia di kelas VII $\mathrm{C}$ adalah kategori pertanyaan guru (Teacher Questions (TQ) yaitu guru yang lebih dominan mengajukan pertanyaan kepada siswa, interaksi yang terjadi adalah interaksi dua arah.

\section{PENUTUP \\ Kesimpulan}

Interaksi yang terjadi dalam pembelajaran Bahasa Indonesia antara guru dengan siswa di kelas VII B dan VII C SMP Negeri 15 Kota Bengkulu bersifat dua arah. Berdasarkan analisis interaksi yang digunakan yaitu analisis BIAS (Brown Interaction Analysis System) kategori yang cenderung muncul pada pembelajaran Bahasa Indonesia di kelas VII B adalah kategori respon siswa (Pupil Respons (PR), siswa lebih banyak berbicara baik berkomentar atau bertanya sehingga interaksi yang terjadi adalah interaksi dua arah.

$\begin{array}{cc}\text { Berkaitan } & \begin{array}{l}\text { dengan empat jenis } \\ \text { dalam }\end{array} \\ \text { keterampilan } & \text { berbahasa, }\end{array}$ keterampilan yang lebih ditekankan pada kompetensi dasar yang diajarkan pada pertemuan pertama dan kedua di kelas VII $B$ adalah keterampilan berbicara, kategori respon siswa (Pupil Respons (PR) dengan keterampilan berbicara dan karakteristik materi yang diajarkan saling memiliki keterkaitan. Pada pembelajaran Bahasa 
Indonesia di kelas VII C kategori yang cenderung muncul adalah kategori pertanyaan guru (Teacher Questions (TQ) yaitu guru lebih mendominasi berbicara seperti bertanya dan interaksi yang terjadi juga bersifat dua arah.

Materi yang diajarkan pada pertemuan pertama dan kedua di kelas VII $C$ mengenai surat pribadi dan surat dinas, sehingga keterampilan yang lebih ditekankan adalah keterampilan menulis. Oleh sebab itu, selama kegiatan pembelajaran interaksi dua arah lebih mendominasi hal ini sesuai dengan materi dan keterampilan yang harus dicapai. Interaksi yang terjadi memiliki keterkaitan erat dengan karakteristik materi dan keterampilan yang harus dicapai oleh siswa setelah pembelajaran selesai. Karakteristik materi yang diajarkan di kelas VII B dan VII $C$ berbeda, begitu juga dengan keterampilan yang harus dicapai namun interaksi yang mendominasi di kedua kelas tersebut selama proses pembelajaran sama-sama bersifat dua arah.

\section{Saran}

Berdasarkan hasil penelitian yang telah dilakukan, untuk penelitian selanjutnya disarankan:

1. Penelitian mengenai analisis interaksi guru dan siswa di kelas VII SMP Negeri 15 Kota Bengkulu ini masih sangat sederhana. Oleh sebab itu, perlu dilakukan penelitian agar lebih diperoleh hasil yang lebih maksimal dan meningkatkan mutu penulisan karya tulis ilmiah bagi pembaca.

2. Pada saat pengambilan data perlu memperhatikan hal-hal penting untuk menindaklanjuti hasil perbaikan pembelajaran.

\section{DAFTAR PUSTAKA}

Hadiat. 1980. Analisis Interaksi. Jakarta: Proyek Pengembangan Pendidikan Guru (P3G) Departemen Pendidikan dan Kebudayaan.

Muslich, Masnur dkk. 1987. Dasar-Dasar Interaksi Belajar Mengajar Bahasa Indonesia. Malang: Jemmars.

Samana, A. 1992. Sistem Pengajaran Prosedur Pengembangan Sistem Instruksional (PPSI) dan Pertimbangan Metodologisnya. Yogyakarta: Kanisius.

Sardiman, A.M. 2010. Interaksi dan Motivasi Belajar Mengajar. Jakarta: PT RajaGrafindo Persada.

Supriyadi. 2011. Strategi Belajar dan Mengajar. Yogyakarta: Cakrawala IImu.

Sutikno Sobry, M. 2009. Belajar dan Pembelajaran: Upaya Kreatif dalam Mewujudkan Pembelajaran yang Berhasil. Bandung: Prospect. 